\title{
〔29〕ナイロン 6 の結晶化に関する研究
}

第 4 報 等温結晶化速度の分子量・温度依存性

(1968 年 8 月19日受理)

石橋 徹*.谷 八紘*

要 旨 ナイロン 6 の等温結晶化挙動の分子量・温度依存性を偏光透過光強度测定法により検討し た。試料の数平均分子量 $\bar{M}_{n}$ は $2.6 \times 10^{3} \sim 1.9 \times 10^{4}$ の範囲にある 7 種, 結晶化温度は 100,160 , $190^{\circ} \mathrm{C}$ であった。測定結果を Avrami プロットして整理すると分子量が低くて結晶化温度の高い場合 に結晶化初期において束状成長・均一核発生と解される定数 $n$ の值が 6 に近い場合があるが, 他はすべ て 4 であった。したがって動力学的解析においては結晶化が $1 / 2$ 進行するに要する時間 $t_{1 / 2}$ の逆数で結 晶化速度を表わし, $n=4$ と近似した。その結果は

$\ln \left(\frac{1}{t_{1 / 2}}\right)=\ln T-\left(\frac{E_{D}([\eta])}{R T}\right)+\frac{C_{3}([\eta])}{n}-\left[\frac{C_{4}([\eta])}{n T\left\{T_{m}([\eta])-T\right\}}\right]$ ここで $n=4:$ Avrami 定数, $T:$ 結 晶化温度 $\left({ }^{\circ} \mathrm{K}\right), E_{D}([\eta])=E_{\imath \iota x}([\eta]) / \rho([\eta])$ : ポリマー輸送の活性化自由エネルギー (cal $\left./ \mathrm{mal}\right)$, $E_{v i s}([\eta])=4.12 \times 10^{3} T^{2}\left\{51.6+T-T_{g}([\eta])\right\}^{-2}:$ 粘性流動の活性化自由エネルギー (cal $\left./ \mathrm{mol}\right), T_{0}$ $([\eta])=581.6-1076 \times(1.81[\eta]+13.45)^{-1 / 2}:$ ガラス転移点 $\left({ }^{\circ} \mathrm{K}\right), \rho([\eta])=-8.3[\eta]+20.2: E_{v i s}$ と $E_{D}$ の比を表わす温度に依存しない定数, $[\eta]$ : 固有粘度数 (メタクレゾール溶液), $R$ : ガス定数, $C_{3}$ $([\eta])=(0.309-0.206[\eta])^{-1}-8.5$ および $C_{4}([\eta])=10^{5}(0.82-0.52[\eta])^{-1}+2.5 \times 10^{5}$ : 温度に依存しな い定数, $T_{m}([\eta])=\left\{1 / 504+6.125 \times 10^{-6} /[\eta]^{1.435}\right\}^{-1}$ : 融点 $\left({ }^{\circ} \mathrm{K}\right)$ 。結晶化速度が最大になる温度 $T_{\max }$, $E_{D}, \rho, C_{3}$ に含まれる結晶化に伴ら活性化エントロピー， $C_{4}$ から求められる結晶核表面自由エネルギ 一および臨界核寸法はいずれも分子量に依存する。これらの意義について考察した。

\section{1. 緒言}

ナイロン 6 の溶融状態からの等温結晶化速度の分子量 依存性については井上" ${ }^{1}$, Magill2) の報告がある。前者 はディラトメトリーにより数平均重 合度が $130\left(\bar{M}_{n}=\right.$ $\left.1.47 \times 10^{4}\right)$ と $400\left(\bar{M}_{n}=4.52 \times 10^{4}\right)$ の 2 種の試料を用 いて結晶化温度 $205,207^{\circ} \mathrm{C}$ での結晶化速度を測定し高 分子量の方が速度が小さいことを示した。後者は $M_{n}=$ $5 \times 10^{3} \sim 2.9 \times 10^{4}$ の範囲にある 8 種の試料について結 晶化温度 $211^{\circ} \mathrm{C}$ での結晶化誘導時間てを偏光顕微鏡のク ロスニコル下で測定し， $\tau$ は $M_{n} \fallingdotseq 10^{4}$ までは分子量の増 大とともに増大し， $\bar{M}_{n} \geq 10^{4}$ ではほぼ一定でわずかなが

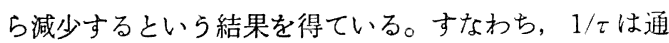
常結晶化速度と併行関係にあるから， $\bar{M}_{n} \geq 10^{+}$では前者 と逆の結果を得たことになる。しかしながら，前者では 分子量依存性の詳細を知るには試料数が少なく, 後者で はてのみの测定で結晶化挙動の詳細な検討は困難である。 また，これらの測定は結晶化速度の非常に遅い融点に近 い高温域に限られている。われわれはこの研究の前に, すでに第 $1 ， 2$ 報 $^{31,4)}$ で述べたよ5に，速度のきわめて 速い結晶化温度域での測定方法とその試料の絬晶化の進 行を偏光透過光強度を測定することそよりって可能とし

*東洋紡績株式会社緎維研究所（嵫貿県大津市本堅田 町)
た。さらに第 3 報5) では $\bar{M}_{n}=1.9 \times 10^{4}$ の試料の 85 $180^{\circ} \mathrm{C}$ の範囲にわたって結晶化速度とともに球晶成長を も測定した。そして両者に関する統一した温度依存式を 提出した。本報では $\bar{M}_{n}=2.6 \times 10^{3} \sim 1.9 \times 10^{4}$ の範囲の 7 種の試料について結晶化温度 $100,160,190^{\circ} \mathrm{C}$ での 結晶化速度を测定し定量的な知見を得ようとした。

\section{2. 実験}

\section{1 分子量の異なる試料の調製}

とーカプロラクタムに常に $0.4 \%$ の水拉よび種々の量 の酢酸（分子量調節剤）を添加し， $260^{\circ} \mathrm{C} て ゙ 24$ 時間封 管中で加熱することによって 7 種の試料を製造した。重 合後の各試料は粉确してメタノールで 20 時間ソックス レ一抽出してモノマーやオリコマーを除き,さらに $100^{\circ} \mathrm{C} て ゙ 24$ 時間減王乾燥して結晶化実験に供した。

\section{2 試料の分子量および融点の測定}

数平均分子量 $\bar{M}_{n}$ は末端基定量法により求めた。固有 粘度数 $[\eta]$ はメタクレゾール溶液に対する福本 ${ }^{6)}$ の提出 した粘度式（1）を用いて算出した。

$$
\bar{M}_{n}=14400[\eta]^{1.435}
$$

融点 $T_{m}$ は $215^{\circ} \mathrm{C} て ゙ 24$ 時間結晶化させた試料フィル ムを加熱台付偏光顕微鏡のクロスニコル下で約 $0.1^{\circ} \mathrm{C} /$ min の速度で昇温させながら偏光透過光が消隇し終ると きの温度により決めた。これらの値は Table 1 に示す。 
Table 1. Characteristics of nylon 6 samples.

\begin{tabular}{c|c|c|c}
\hline \hline Sample & $\bar{M}_{n} \times 10^{-3 *}$ & {$[\eta] * *$} & $T_{m}{ }^{* * *}\left({ }^{\circ} \mathrm{K}\right)$ \\
\hline A & 19.0 & 1.21 & 503 \\
B & 16.1 & 1.08 & 503 \\
C & 13.8 & 0.97 & 502 \\
D & 10.1 & 0.78 & 502 \\
E & 8.3 & 0.68 & 501 \\
F & 4.4 & 0.44 & 499 \\
G & 2.6 & 0.30 & 495 \\
\hline
\end{tabular}

* Number-average molecular weight, $\bar{M}_{n}$ determined by the end group titration method.

** Intrinsic viscosity, [ $\eta]$ calculated from methacresol solution of nylon 6, proposed by Fukumoto $: \bar{M}_{n}=14400[\eta]^{1.435}$.

*** Melting point, $T_{m}$ determined by polarizing microscope on which mounted hot stage.

\section{3 結晶化速度の測定}

これについては既報のごとく相当詳細に検討した方

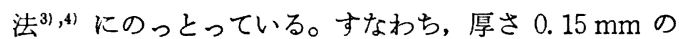
2 枚のカバーガラスに試料ポリマーが約 $20 \mu$ になるよ らにセットし, 特製加熱炉中で $290^{\circ} \mathrm{C}, 1$ 分間融解し, その直後一定温度に保った水銀浴中に浸漬して等温結晶 化させた。そしてストップウォッチで測って一定時間後 ドライアイスーメタノール中に投入して凍結させた。結 晶化時間の異なる一連の試料の偏光透過光強度をミク口 フォトメーター, 直交偏光板, シックネスゲージを用い て求めた。結晶化前の融解条件はすべて $290^{\circ} \mathrm{C}, 1$ 分と した。Fig 1 は結晶化完了後の試料フィルムを偏光顕硙 鏡のクロスニコル下で観察したときに視野内にみられる 最大球晶直径 $\alpha_{\max }$ の融解温度による变化を示したもの である。たたし，試料 Aを用い，融解時間を 1 分，結晶 化温度を $160^{\circ} \mathrm{C}$ 一定とした。 $\alpha_{\max }$ は融解温度 $260^{\circ} \mathrm{C}$ 以 上で一定となり結晶化速度に及ぽす熱履歴効果のなくな ることがわかる。

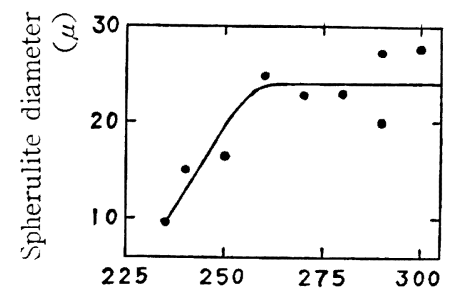

Pre-melting temperature $\left({ }^{\circ} \mathrm{C}\right)$

Duration of pre-melting: $1 \mathrm{~min}$.

Fig. 1. The effect of the pre-melting temperature on the maximum diameter of spherulites attained by isothermal crystallization at $160^{\circ} \mathrm{C}$.

\section{4 等温結晶化挙動の解析法}

結晶化時間が 0 秒， $t$ 秒後および結晶化完了後の偏光 透過光強度をそれぞれ $I_{0}, I_{t}, I_{\infty}$ とすると非結晶分率 $\theta$ は $\theta=\left(I_{\infty}-I_{t}\right) /\left(I_{\infty}-I_{0}\right)$ で表わされ, Avrami の

（2）式を用いて解析した。

$$
\theta=\exp \left(-K t^{n}\right)
$$

ここで $K$ は結晶化速度定数, $n$ は Avrami 定数であ る。結晶化速度のパラメーターとして $\theta=1 / 2$ となるに 要する時間の逆数 $1 / t_{1 / 2}$ を採用した。 $1 / t_{1 / 2}$ は $K$ と次 の関倸がある。

$$
\frac{1}{t_{1 / 2}}=\exp \left\{\frac{\ln K-\ln \ln 2}{n}\right\}
$$

\section{3. 結果と考察}

\section{1 等温結晶化挙動}

Fig. 2，3，4 にそれぞれ 100，160，190 Cに打る 各試料の $\theta$ の $\log t$ による变化を示した。実線は $n=4$ の場合の理論曲線であり, $100^{\circ} \mathrm{C}$ の場合, 実験値のプロッ トは実線にのるが. $190^{\circ} \mathrm{C}$ おび $160^{\circ} \mathrm{C}$ の低分子量試 料では結晶化初期においていくらかのずれが見られる。 $\log \ln (1 / \theta)$ 対 $\log t$ のプロット (以下 Avrami プロッ トと略記）をすると， Fig. 5，6，7 に示すように $n$ 値を表わす勾配は $100^{\circ} \mathrm{C}$ の場合, $n=4$ と一定であるが 上記の特別なケースにおいて $n=6$ となる。 $n=6$ の部分 では一次核が一定の割合で発生し, それが球晶形態にな るまでの初期形態である束状での成長によるものと考兄 られる。Photo 1, 2 は試料Cを $190^{\circ} \mathrm{C} て ゙$ 結晶化させ, Avrami プロットの折れ曲り前の $t=12$ 秒と結晶化が ほぼ終った $t=50$ 秒後にそれぞれ凍結した試料フィルム の偏光顕微鏡写真である。Photo 1 では通常の球晶成長 の初期形態（小球体）とは異なり，見かけ上棒状である。 これは結晶核の凝集密度の高い束状体の中心部のみが観

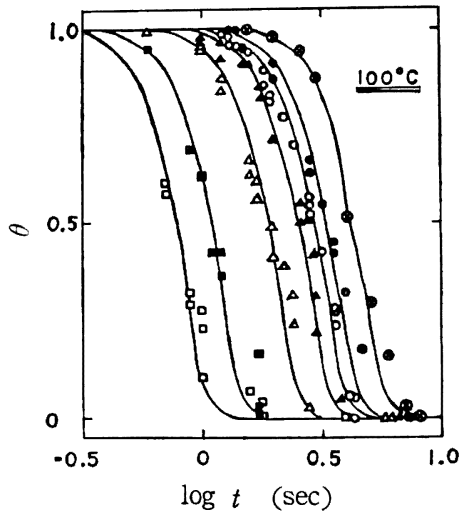

$\otimes: A, \bullet: B, O: C, \Delta: D, \triangle: E, \square: F, \square: G$

Fig. 2. Plots of $\theta=\left(I_{\infty}-I_{t}\right) /\left(I_{\infty}-I_{0}\right)$ against $\log t$ for isothermal crystallization temperature $100^{\circ} \mathrm{C}$ of the samples of $\mathrm{A} \sim \mathrm{G}$. 


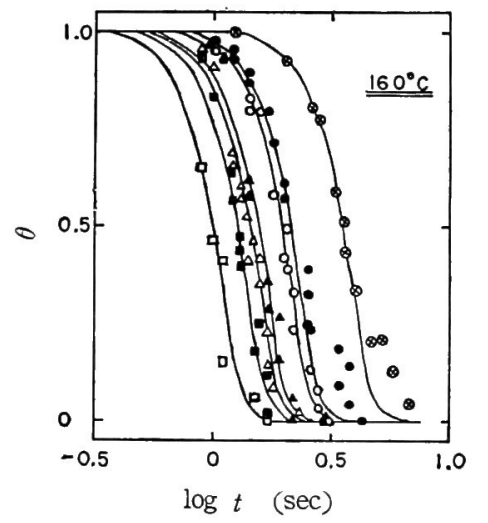

$\otimes: A, \bullet: B, O: C, \Delta: D, \triangle: E, \bullet: F, \square: G$

Fig. 3. Plots of $\theta$ against $\log t$ for isothermal crystallization temperature $160^{\circ} \mathrm{C}$ of the samples of $A \sim G$.

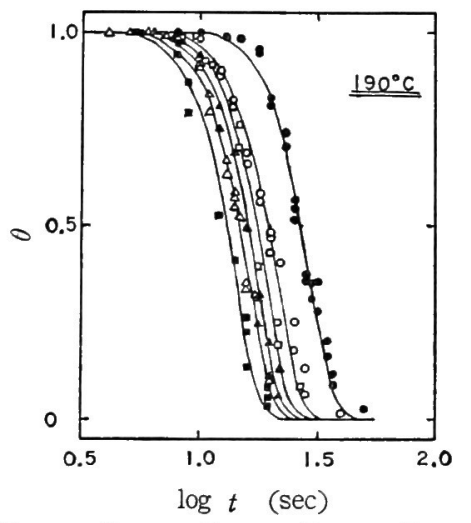

- : B, $\bigcirc: C, \triangle: D, \triangle: E, \mathbf{a}: F, \square: G$,

Fig. 4. Plots of $\theta$ against $\log t$ for isothermal crystallization temperature $190^{\circ} \mathrm{C}$ of samples of $B \sim G$.

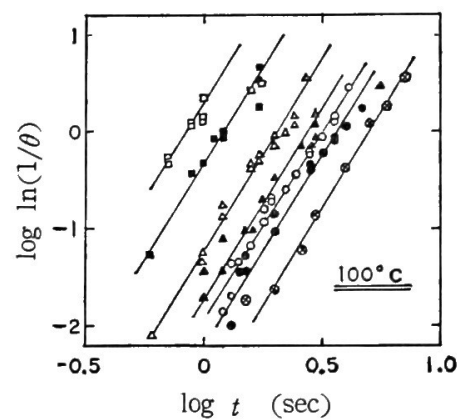

$\otimes: A, \bullet: B, O: C, \Delta: D, \triangle: B, \bullet: F, \square: G$

Fig. 5. Plots of $\log \ln (1 / \theta)$ against $\log t$ for samples of $A \sim G$ at crystallization temperature $100^{\circ} \mathrm{C}$.
察されたことによるものであろう。Photc 2 ははっきり した球晶形態ではなく、くずれた形となっている。束状 成長がある程度進行後球晶成長するわけであるが，この ものが試料フィルム厚さ方向にいくつか重なったことに よってこのよらに観察されたと考えられる。

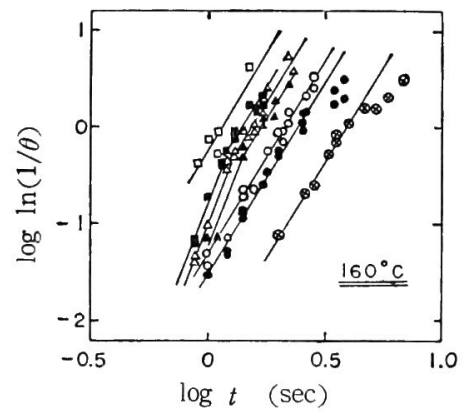

$\otimes: A, \bullet: B, O: C, \triangle: D, \triangle: E$, 回: F, $\square: G$

Fig. 6. Plots of $\log \ln (1 / \theta)$ against $\log t$ for samples of $A \sim G$ at crystallization temperature $160^{\circ} \mathrm{C}$

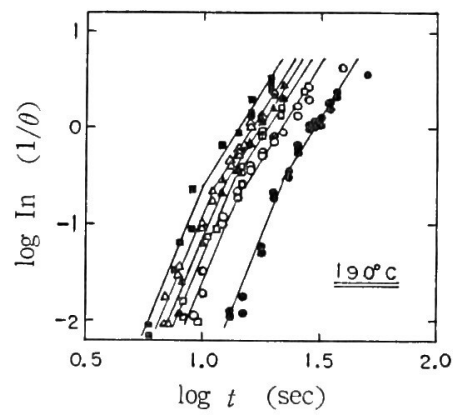

- : $\mathrm{B}, \bigcirc: \mathrm{C}, \Delta: \mathrm{D}, \triangle: \mathrm{E}, \mathbf{\mathrm { m }}: \mathrm{F}, \square: \mathrm{G}$

Fig. 7. Plots of $\log \ln (1 / \theta)$ against $\operatorname{lcg} t$ for samples of $B \sim G$ at crystallization temperature $190^{\circ} \mathrm{C}$.

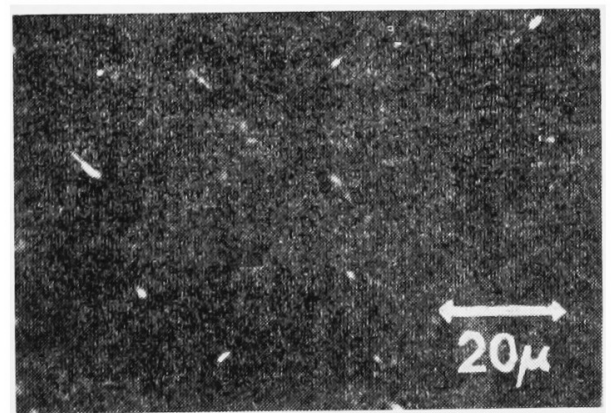

Photo. 1. Polarized microscope photograph of quenched sample $C$ film in the course of crystallization at $t=12 \mathrm{sec}$.

Crystallization temperature $: 190^{\circ} \mathrm{C}$ 


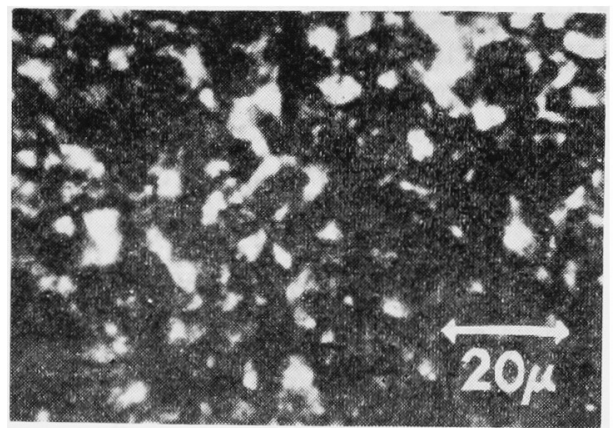

Photo. 2. Polarized microscope photograph of quenched sample $C$ film in the course of crystallization at $t=50 \mathrm{sec}$.

Crystallization temperature: $190^{\circ} \mathrm{C}$.

上出ら゙る㣫々のポリプロピレン試料についてディラ トメーターにより結晶化の進行を測定し直接 Avrami プロットをすると本実駼結果と同粎の折れ曲りの生じる 絬果を得た。そして高楖ら ${ }^{8)}$ がポリエチレンアジペート について同じ测定法による結果に対して指摘したと同 滕, 結晶化浴に浸湍後, 試料がその温度になるまでに要 した時間」の補正が必要であるとし，」の実測值を」 として $\log \log (1 / \theta)$ を $\log \left(t-J^{\prime}\right)$ に対して描き直 すと折れ曲りが消失することを示した。ディラトメータ 一による测定では少なくとも $1 \mathrm{~g}$ 沙後の試料を必要と乙 $1.5 \mathrm{~g}$ の試料を用いた上出らの実娩でざは約 5 分であっ た。この測定法でしかも結晶化速度の速い温度域では確 かに」の補正が必要であるといえよう。

われわれは結晶化速度の速いナイロン 6 の広い温度域 で通用しらる实蚠方法を娭討してきだ”。そこで示した よらに $290^{\circ} \mathrm{C}$ の融解温度から $100^{\circ} \mathrm{C}$ の結晶化温度まで の試料の汾却時間は 0.14 秒程度であった。したがって 上に述べた」の補正は無視できるものと考光られる。 以上のことから本实験で認められた Avrami プロット の折れ曲りは本犋的に成長様式の想化に基くものと判断 される。

ところで，折れ曲りの起こる時間は $t^{\prime}$ はすべて $t^{\prime}<$ $t_{1 / 2}$ であり, $t^{\prime}$ は $25 \sim 35 \%$ 結唱化谁行時であることに 注目寸る必要がある。それで以後の解析ておいて結晶化 速度のパラメーターを $1 / t_{1 / 2}$ で表わし, 結果のすべてを 近似的に $n=4$ として取り扱らことにする。このような 取扱はいくらか便宜的ではあるけれども統一的な解积を 妨げるものではない。Fig. 2〜7 より求めた等温結晶化 の諸定数を Table 2 に示す。

\section{2 結晶化速度の分子量 ·温度依存式}

\section{2 .1 結晶化速度の温度依存式}

前報 に林いて $\bar{M}_{n}=1.9 \times 10^{4}$ (試料A)について球晶
Table 2. The effect of molecular weight and temperature on the isothermal crystallization kinetics of nylon 6 .

\begin{tabular}{|c|c|c|c|c|}
\hline $\begin{array}{l}\text { Temp. of } \\
\text { crystalli- } \\
\text { zation }\left({ }^{\circ} \mathrm{C}\right)\end{array}$ & Sample & $\begin{array}{c}\text { Avrami's } \\
\text { constant } \\
n\end{array}$ & $\begin{array}{c}\text { Half } \\
\text { time } \\
t_{1 / 2} \\
\text { (sec) } \\
\end{array}$ & $\begin{array}{c}\text { Crystalli- } \\
\text { zation rate } \\
1 / t_{1 / 2} \\
\left(\mathrm{sec}^{-1}\right)\end{array}$ \\
\hline \multirow{7}{*}{100} & A & 4 & 4. 19 & 0.239 \\
\hline & B & 4 & 3. 31 & 0.302 \\
\hline & C & 4 & 2.95 & 0.339 \\
\hline & D & 4 & 2.51 & 0.399 \\
\hline & $\mathrm{E}$ & 4 & 1.91 & 0.524 \\
\hline & F & 4 & 1. 10 & 0.910 \\
\hline & G & 4 & 0.78 & 1. 282 \\
\hline \multirow{7}{*}{160} & A & 4 & 3.55 & 0.282 \\
\hline & B & 4 & 2. 14 & 0.467 \\
\hline & $\mathrm{C}$ & 4 & 1. 95 & 0.513 \\
\hline & $\mathrm{D}$ & $(6), 4$ & 1. 52 & 0.658 \\
\hline & $\mathrm{E}$ & $(6), 4$ & 1. 45 & 0.690 \\
\hline & F & $(6), 4$ & 1. 27 & 0.787 \\
\hline & G & $(6), 4$ & 1.00 & 1.000 \\
\hline \multirow{6}{*}{190} & $B$ & (6), 4 & 27.10 & 0.0369 \\
\hline & $\mathrm{C}$ & $(6), 4$ & 19.95 & 0.0501 \\
\hline & $D$ & $(6), 4$ & 15.85 & 0.0631 \\
\hline & $\mathrm{E}$ & $(6), 4$ & 14.65 & 0.0681 \\
\hline & F & $(6), 4$ & 12. 95 & 0.0773 \\
\hline & G & $(6), 4$ & 17. 78 & 0.0562 \\
\hline
\end{tabular}

成長速度および結晶化速度の温度依存性を梌討して 1 次 核および 2 次核ともに $J T^{-1}$ 則の成立することを示し た。そして結晶化速度定数 $K$ の温度依存式は（4）式で 表わせた。

$$
\ln \left(\frac{K}{T^{4}}\right)=\ln K_{0}-\frac{4 E_{D}}{R T}-\frac{\left(3 C_{1}+C_{2}\right)}{T \Delta T}
$$

ここで $K_{0}$ は温度に依存し灰い定数, $E_{D}$ は結晶核表面 へのポリマー鎖輸送の活性化エネルギー*1 で, 粘性流動

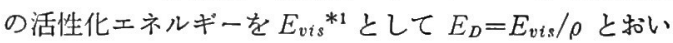
たとき， $\rho=10$ がよく実験結果を満足させた。Rはガス 定数, $\Delta T=T_{m}-T, C_{1}$ 扰よび $C_{2}$ はそれぞれ 2 次核，打 よび 1 次核生成の自由エネルギーに関係した温度に依存 しない定数である。右辺第 2 項の係数 4 扩よび第 3 項の 分子にかかる係数は均一核発生球晶成長 $(n=4)$ に由来 する。

$K$ を結晶化速度のパラメーター $1 / t_{1 / 2}$ でおきか方る と,

$$
n \ln \left(\frac{1}{t_{1 / 2}}\right)=n \ln T+C_{3}-\frac{n E_{v i s}}{\rho R T}-\frac{C_{4}}{T \Delta T}
$$

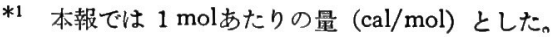


ここで $C_{3}=\ln K_{0}-\ln \ln 2, C_{4}=3 C_{1}+C_{2}$ である。

(5)式および前記した実験結果をもとにして $1 / t_{1 / 2}$ の分子量・温度依存式を導いてみる。それには(5)式中 の分子量に依存する係数 $E_{v i s}, \rho, C_{3}, C_{4}, T_{m}$ を分子量 （ク］で表わすことにする）の関数で表わす必要がある。

\section{$3.2 .2 E_{v i s}$ の分子量・温度依存式}

$E_{\text {七s }}$ はWLF 式を絶対温度の逆数で偏微分して得ら れ, $T$ およびガラス転移点 $T_{g}$ の関数として次のように 表わせる。

$$
E_{v i s(w)}=\frac{4.12 \times 10^{3} T^{2}}{\left\{51.6+T-T_{0}([\eta])\right\}^{2}}
$$

ここで $T_{g}$ の分子量依存值 $T_{\theta}([\eta])$ はWLF 式の適用温 度範囲が拆張できると仮定し次のようにして求めた。向 山ら ${ }^{9}$ は $[\eta]=0.42 \sim 1.58$ にある 10 種のナイロン 6 試料 について試作した共軸円筒回転粘度計により溶融粘度を $493 \sim 530^{\circ} \mathrm{K}$ の範囲にわたって测定し, 粘性流動の活性

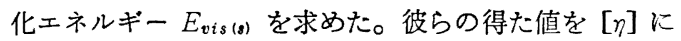
対してプロットするとほぼ直線関保がなりたち, 最小二 乗法により実験式をつくると

$E_{v i s(s)},{ }_{493 \sim 530}{ }^{\circ} \fallingdotseq(1.81[\eta]+13.45) \times 10^{3}$

$E_{v i s(s)}$ は啟密には $E_{v i s(w)}$ のように温度に依存するは ずであるが，ここでは測定範囲がせまいために見かけ上

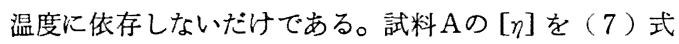
に代入すると， $E_{v i s(s)}=15.64 \mathrm{kcal} / \mathrm{mol}$ となる。また (6)式に $T=530^{\circ} \mathrm{K}, T_{g}=310^{\circ} \mathrm{K}$ (和田 ${ }^{10)}$ が誘電率から 求めたナイロン 6 の $\alpha$ 分散の温度で, 後に著者が試料 $\mathrm{A}$ についてディラトメーターによる比容積 - 温度曲線から 求めた $T_{g}$ とも一致した）を代入すると， $E_{v i s(w)}=15.69$ $\mathrm{kcal} / \mathrm{mol}$ となり, 両者はきわめてよく一致する。そこ で $E_{v i s(w)}, 530^{\circ} \mathrm{K}=E_{v i s(s)},{ }_{493} \sim 530^{\circ} \mathrm{K}$ とおいて次式を得 る。

$$
T_{\theta}([\eta])=581.6-\frac{1076}{(1.81[\eta]+13.45)^{0.5}}
$$

\section{3. $2.3 \sigma, C_{3}, C_{4}$ の分子量依存式}

前報 ${ }^{51}$ に拈いて $M_{n}=1.9 \times 10^{4}$ の試料では $\rho=10$ のと き $\Delta T^{-1}$ 則がなりたつことを示した。それで同じ処方で $\Delta T^{-1}$ 則がなりたつための $\rho$ 值を各試料について決定し た。その結果は Fig. 8に示すよらに $[\eta]$ に対しほぼ直 線関係があり，最小二乗法により(9)式を得る。

$$
\rho([\eta])=20.2-8.3[\eta]
$$

Fig. 9 に $4\left\{\ln \left(1 / t_{1 / 2}\right)-\operatorname{in} T+\left(1 / \rho([\eta]) E_{v i s}(T,[\eta])\right.\right.$ $/ R T\}$ 対 $1 / T \Delta T$ のプロットを示す。たたし, $\rho([\eta])$ は $1 / t_{1 / 2}$ の測定誤差の影響を少しでも除くために( 8 )式 による計算値を用いた。Fig. 10 は Fig. 9 と同じプロ ットを $1 / T \Delta T^{2}$ に対して行なったもので両者の間に直線 関播はなりたたない。むりに $J T^{-2}$ 則をなりたたせよう とするとさらに大きい $\rho$ 值を必要とする。このことから

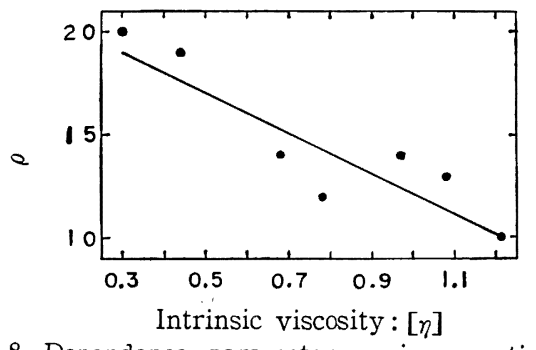

Fig. 8. Dependence parameter $\rho$ in equation (5) upon intrinsic viscosity [ $\eta]$.

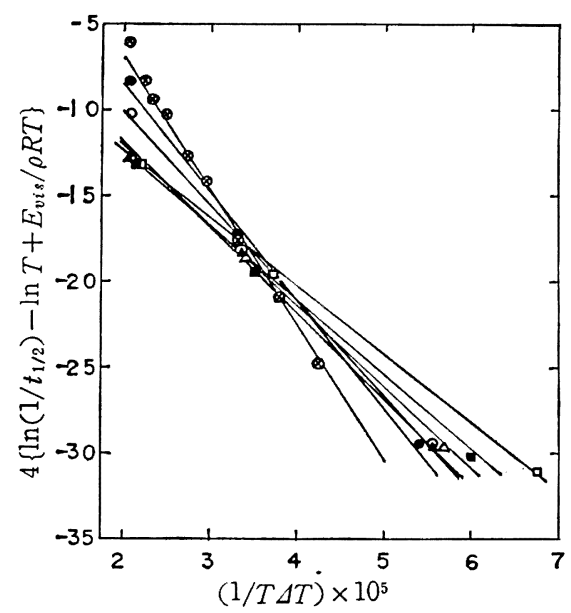

Fig. 9. Plots of $4\left\{\ln \left(1 / t_{1 / 2}\right)-\ln T+E_{v i s} / \rho R T\right\}$ against $1 / T \Delta T$. Used $\rho$ value calculated by equation (9).

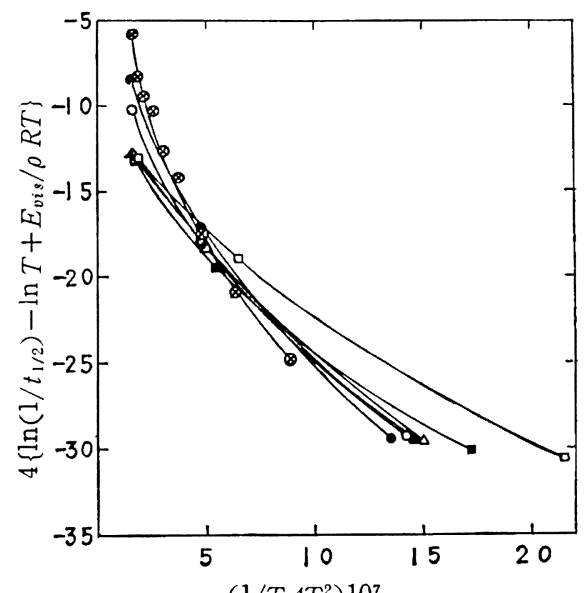

Fig. 10. Plots of $4\left\{\ln \left(1 / t_{1 / 2}\right)-\ln T+E_{v i s} / \rho R T\right\}$ against $1 / T \Delta T^{2}$. Used $\rho$ value calculated by equation ( 9 ). 


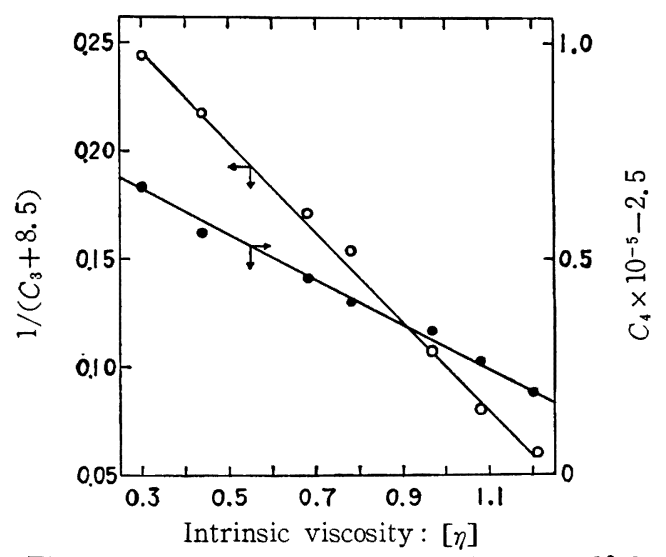

Fig. 11. Plots of $1 /\left(C_{3}+8.5\right)$ and $1 /\left(C_{4} \times 10^{-5}\right.$ 2.5) against intrinsic viscosity $[\eta]$.

ナイロン 6 の場合分子量が異なっても 1 次核， 2 次核と もに $\Delta T^{-1}$ 則(これらの臨界核の一方向の長さが温度に関 せず一定）がなりたつと考えることが妥当と思われる。

Fig. 9 の直線の $1 / T \Delta T=0$ での縦軸の值および勾配 からそれぞれ各試料の $C_{3}, C_{4}$ が求められる。Fig. 11 に示すように $1 /\left(C_{3}+8.5\right)$ および $1 /\left(C_{4} \times 10^{-5}-2.5\right)$ を $[\eta]$ に対してプロットするといずれも直線となるの で， $C_{3}$ および $C_{4}$ の分子量依存式はそれぞれ!(10)およ び(11)式で表わされる。

$$
\begin{aligned}
& C_{3}([\eta])=\frac{1}{0.309-0.206[\eta]}-8.5 \\
& C_{4}([\eta])=\frac{10^{5}}{0.82-0.52[\eta]}+2.5 \times 10^{5}
\end{aligned}
$$

\section{3. $2.4 T_{m}$ の分子量依存式}

数平均重合度が $\bar{P}_{n}$ であるポリマーの融点 $T_{m}$ は Flory の理論 ${ }^{11}$ によれば次式で与えられる。

$$
\frac{1}{T_{m}}-\frac{1}{T_{m i}{ }^{0}}=\frac{2 R}{\Delta H_{u} \bar{P}_{n}}
$$

ここで $T_{m}{ }^{0}$ は十分に大きい重合度の平衡融点, $\Delta H_{u}$ は 結晶の基本モルあたりの融解熱である。Table 1 に示し た $T_{m}$ の実測値が(12)式によく適合することは Fig. 12 に見られる通りである。これから $T_{m}{ }^{0}=504^{\circ} \mathrm{K}, \Delta H_{u}=$ $5.1 \times 10^{3} \mathrm{cal} / \mathrm{mol}(=45.1 \mathrm{cal} / \mathrm{g})$ が得られる。 $\Delta H_{\text {いは }}$ 井上 ${ }^{12)}$ が示差熱分析法で得た $45 \mathrm{cal} / \mathrm{g}$ ，また, Dole ら ${ }^{131}$ が得た $45 \mathrm{cal} / \mathrm{g}$ とよく一致する。したがってナイロン 6 の $T_{m}$ の分子量依存式として

$$
\frac{1}{T_{m}\left(\bar{P}_{n}\right)}-\frac{1}{504}=\frac{7.8 \times 10^{-4}}{\bar{P}_{n}}
$$

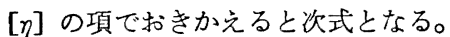

$$
\frac{1}{T_{m}([\eta])}=\frac{1}{504}+\frac{6.125 \times 10^{-6}}{[\eta]^{1.435}}
$$

\subsection{5 結晶化速度の分子量・温度依存式}

結晶化速度の分子量・温度依存式は(5)式の分子量に

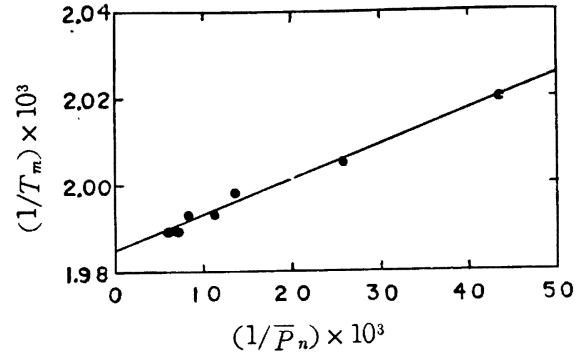

Fig. 12. Graphical presentation of the melting point of nylon 6 samples with different degree of polymerization $\bar{P}_{n}$ by Flory's equation.

依存する係数を $[\eta]$ の関数として次のように曺きかえら れる。

$$
\begin{aligned}
\ln \left(\frac{1}{t_{1 / 2}}\right)=\ln T & -\frac{E_{v i s}([\eta], T)}{\rho([\eta]) R T}+\frac{C_{3}([\eta])}{n} \\
& -\frac{C_{4}([\eta])}{n T\left(T_{m}([\eta])-T\right)}
\end{aligned}
$$

ここで $E_{v i s}([\eta], T), \rho([\eta]), C_{3}([\eta]), T_{m}([\eta])$ はそ れぞれ(6)，（9），(10)，(11)，(14)式で与えられる。

（15）式より計算した結晶化速度を結晶化温度および [ク]に対してそれぞれ Fig. 13，Fig. 14 に実線で示し た。ポイントの実験值と比較してこの程度ならよく一致 しているといえよう。

\section{3 結晶化諸特性に及ぼす分子量の効果について}

\section{3. $3.1 T_{\mathrm{mux}}$}

Fig. 13 の計算曲線から得られる $1 / t_{1 / 2}$ が最大となる 温度 $T_{\max }$ の分子量依存性は試料の特性值 $T_{m} お$ よび

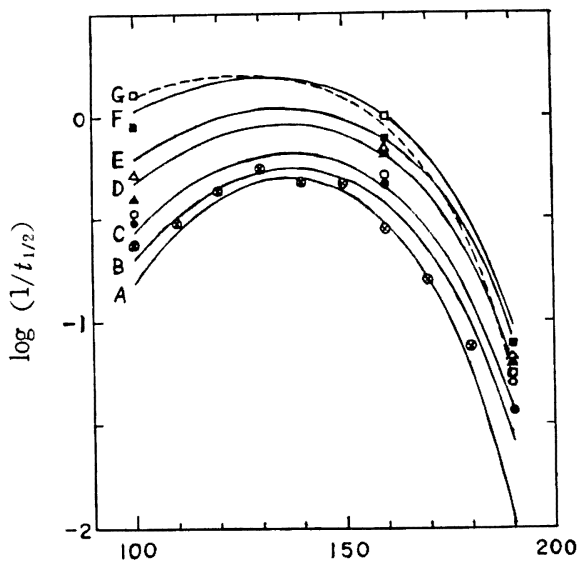

Crystallization temperature $\left({ }^{\circ} \mathrm{C}\right)$

Fig. 13. Dependence of $\log \left(1 / t_{1 / 2}\right)$ upon crystallization temperature. Solid and dotted lines calculated by equation (15) for indicated sample. 


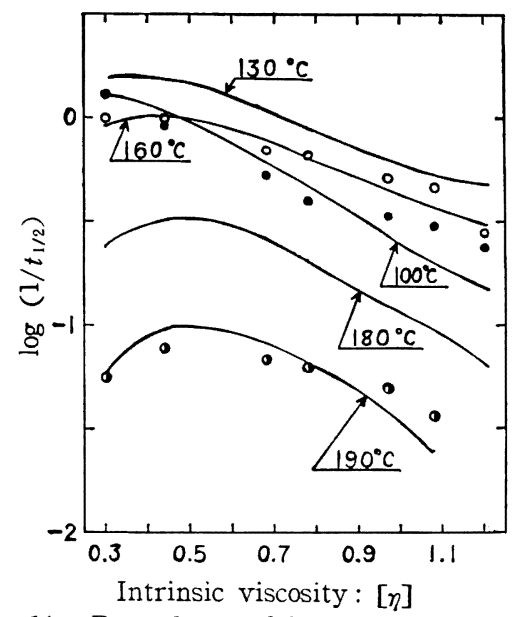

Fig. 14. Dependence of $\log \left(1 / t_{1 / 2}\right)$ upon intrinsic visccsity $[\eta]$ at different crystallization temperatures. Solid lines calculated by equation (15).

$T_{0}$ の関数として表わされるようである。Table 3 に示 すようによい近似で次の関僁が成立する。

$$
T_{\max }=\frac{T_{m}+T_{g}}{2}+5.5
$$

$T_{\max }$ は $\partial\left(1 / t_{1 / 2}\right) / \partial t=0$ となる温度として定義され る。ところで, この式の左辺は $T$ の高次式となるため $T_{\max }$ を具体的に求めることはできないけれども $T_{\mathrm{max}}=$ $f\left(T_{g}, \rho, T_{m}, C_{4}\right)$ なる関数で与えられるはずである。 一般的にいって $T_{\max }$ は $T$ が増大すると, $E_{D}$ が減少 することにより結晶化速度を増大させる効果と, 逆に臨 界核生成の活性化自由エネルギー $\Delta F^{*}$ が增大すること により結晶化速度を減少させる効果のかねあいできまる ものと考学られる。前者は $T_{g}$ および $\rho$ に, 後者は $T_{m}$ および $C_{4}$ にそれぞれ依存している。それでこれらの係 数をすべて前記した $[\eta]$ の関数で置きかえ(16)式を特解 として用いると $\left\{\partial\left(1 / t_{1 / 2}\right) / \partial T\right\}_{T=T \text { max }}=0$ を近似的に 満足することがわかった。したがって分子量変化に伴う 特性值の変化のらち $T_{\mathrm{max}}$ に影響するのは主として $T_{m}$

Table 3. Dependence of temperature $T_{\max }$ at which crystallization rate becomes maximum upon melting temperature $T_{\mathrm{m}}$ and glass transition temperature $T_{\mathrm{g}}$.

\begin{tabular}{c|c|c|c|c|c|c|c}
\hline \hline Sample & $\mathrm{A}$ & $\mathrm{B}$ & $\mathrm{C}$ & $\mathrm{D}$ & $\mathrm{E}$ & $\mathrm{F}$ & $\mathrm{G}$ \\
\hline$\left.{ }^{\mathrm{o}} \mathrm{K}\right)$ & 503 & 503 & 502 & 502 & 501 & 499 & 495 \\
$T_{m}$ & 310 & 308 & 307 & 304 & 302 & 297 & 294 \\
$T_{o}$ & 411 & 411 & 410 & 409 & 407 & 404 & 400 \\
$T_{\max }$ & & & & & & & \\
$\left(T_{m}+T_{o}\right) / 2$ & 412 & 411 & 410 & 408.5 & 407 & 403.5 & 400 \\
+5.5 & & &
\end{tabular}

および $T_{0}$ であると判断される。

3.3 .2 ポリマー鎖輸送の活性化エネルギーとエント ロピー変化および臨界核生成自由エネルギー

結晶化速度に及ぽす分子量の影響を表記特性値に基い ていくらかの考察をしてみる。それに先立って最終的に まとめられた(15)式は結晶化速度の対数値が四つの項の 和として表わされていることを留意したい。ここで右辺 第 1 項は結晶化温度を, 第 2 項は融液側にあるポリマー 鎖が核表面にくりこまれるときの活性化ェネルギー，第 3 項はそのときのェントロピー変化, 第 4 項は臨界核生 成の自由エネルギーをそれぞれ含む式である。これらの 各項の結晶化速度に及ぼす分子量効果を朋らかにするた めに結晶化温度 $190^{\circ} \mathrm{C}$ の場合についての計算值を Fig. 15 に示した。

ポリマー鎖輸送の活性化ェネルギー $E_{D}$ は既述のよ

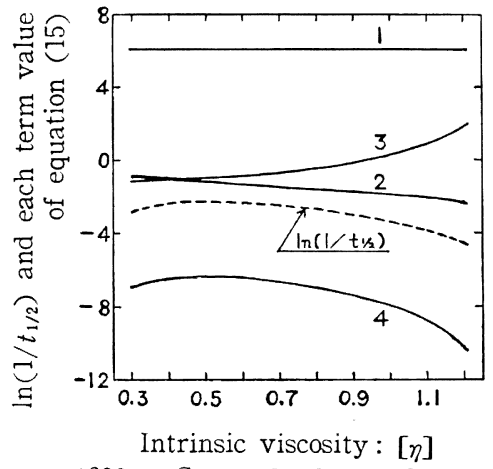

$T=463^{\circ} \mathrm{K}$. Curve 1: In $T$, Curve $2:-E_{D} /$ $R T$, Curve $3: C_{3} / 4$, Curve $4:-C_{4} / 4 T \Delta T$.

Fig. 15. Dependence of $\ln \left(1 / t_{1 / 2}\right)$ upon intrinsic viscosity expressed by the contribution of each term of equation (15)

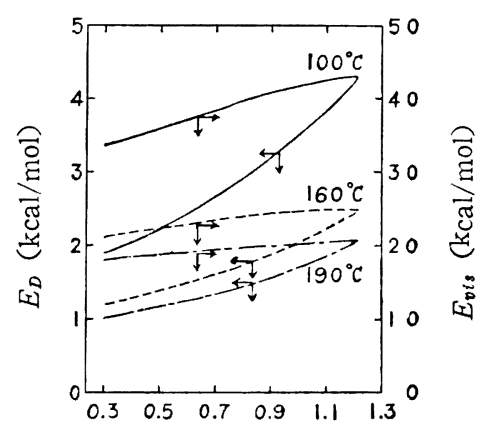

Intrinsic viscosity : [ $\eta]$

Fig. 16. Dependence of the activation energy for the transport of material across the liquid-crystal interface and the activation energy for viscous flow upon intrinsic viscosity $[\eta]$. 
らに $E_{v i s} / \rho$ として表現できた。 $E_{v i s}$ はポリマー鎖セク メントが融液中である位置から次の平衡位置に達するの にそれに連なるセグメントと近傍にあるセグメントと互 いに影響しあいながら飛躍するエネルギー障壁の高さ で，その多くの割合を占めるのはセグメントの入るべき 自由空間の生成エネルギーである(14)。これに対して $E_{D}$ は核表面近くのセグメントがほぼその位置に扎いて結 晶表面の格子に組入れられる過程でのエネルギー障壁の 高さである。これから $\rho>1$ となることが妥当となる。 ところで本実験の結果では。は(9)式あるいわ Fig. 8 に示したよらに分子量が増大すると直線的に減少する ことが示された。このことによって， $E_{D}$ の分子量依存 性は $E_{v i s}$ が $T_{0}$ を通じて分子量に依存する以上に $\rho$ によって顕著に增大するようになる (Fig. 16参照)。 そしてこの項の結晶化速度に対する笴与は Fig. 15 の 曲線 2 で表わされるように分子量の增大するにつれて単 調に減少させるよらになる。

第 3 項 $C_{3}$ は温度に蛙依存しないが, 分子量によって 変化することが示された。この值についてはすでてポリ エチンンアシシペートの小球体成長速度に対する温度・分 子量の関係と題する高柳らの報文 ${ }^{15}$ に解析されている。 それによると $C_{3}$ は Eyring の粘性あるいは拡散理論 にあてはめて結晶核表面にポリマー鎖が移動する場合の 活性化エントロピー」放を含む值である。そしてそこ でもこの値が大きい分子量依存性をもつことが示され た。われわれの実験結果では $C_{3}$ は(10)式で示され, 分 子量の增大するにつれて增大し, 結晶化速度に対しても 増大させる効果があると結論される。これは $J s^{*}$ (負値 をもつ）が分子量增大に伴い, より小さい負值をとるこ とに対応する。

$C_{4}$ は臨界核生成の自由エネルギー $\Delta F^{*}$ あるいはその 表面自由エネルギー $\sigma$ と関係する值である。前報)で $\bar{M}_{n}=1.9 \times 10^{4}$ の試料について明らかにしたよらに球晶 成長速度と結晶化速度は統一した式で表わされることを 示した。そしてこの場合 $C_{1}=1.73 \times 10^{5}, C_{4}=3 C_{1}+C_{2}$ から求めた $C_{2}=2.56 \times 10^{5}$ となった。期待されるように $C_{2}>C_{1}$ であるが両者の差はそれはど大きくない。ここで は便宜的に両者を同等として取り扱う。円柱状核につい ての解析は Hoffman ら ${ }^{16)}$ が取り扱っている。これにな らって核の形状が底辺 $a \cdot b$, 高さ $l_{0}$ (一定)の直方体であ るとしたとき臨界核寸法 $a^{*} \cdot b^{*}$ およびその生成の自由 エネルギー $\Delta F^{*}$ は次の(17), (18) 式で与えられる*2。

$$
\begin{aligned}
& a^{*}=b^{*}=\frac{2 \sigma T_{m}}{\left(T_{m}-T\right) \Delta h_{u}} \\
& \Delta F^{*}=\frac{4 l_{0} \sigma^{2} T_{m}}{\left(T_{m}-T\right) \Delta h_{u}}=\frac{C_{4}}{4} \cdot \frac{R}{N\left(T_{m}-T\right)}
\end{aligned}
$$

*2 ただし融解の自由エネルギー， $\Delta f \cong \Delta h_{u}\left(T_{m}-T\right) / T_{m}$ で 表わされ，かつ $l_{0} \gg 2 \sigma$ と仮定した。

$$
\begin{gathered}
\text { したがって表面自由エネルギー } \sigma \text { は } \\
\sigma^{2}=\frac{R \Delta h_{u} C_{4}}{16 N l_{0} T_{m}}
\end{gathered}
$$

$N$ は Avogadro 数である。 $l_{0}$ としてナイロン 6 の分子 鎖間平均距離である $4.2 \AA, \Delta h_{u}=23.2 \times 10^{8} \mathrm{erg} / \mathrm{cm}^{3}$ $\left(\Delta H_{u}\right.$ より密度 $1.230^{* 3}$ として換算）の值を用いて $\sigma$ 拝 よび $a^{*}$ を求めた。その結果は Fig. 17 に示した。 は分子量の増大により増大する傾向の曲線で示される。 これは核生成にあずかるのはポリマー鎖中のごく一部分 であり，他の大部分は融液側にあってそこでの鎖長が核 近傍でのセグメントの “mobility”, “activity”に寄与 しているものと考えられる。臨界核寸法は結晶化温度が 高くなると增大し， $T_{m}$ に近づくと急激に増大すること は Hoffman ら ${ }^{16)}$ 屯指摘している通りである。(17)式か ら容易に推定されるよらに $T_{m}$ が分子量に大きく影響 されない高分子量領域では $a^{*}$ は $\sigma$ とほぼ比例する。 しかし低分子量領域では $T_{m}$ が大きく低下し分母の $\left(T_{m}-T\right)$ が減少することがきいて逆に増大するように なる。結晶化温度が高い場合にその傾向は顕著になる。 $[\eta]=0.7$ での $a^{*}$ から臨界核に含まれるポリマー鎖の 基本構造単位の数を概算 ${ }^{* 4}$ すると, 結晶化温度 100,160 , $190^{\circ} \mathrm{C}$ でそれぞれ 12，41，131 となる。この值から臨 界核の大きさには何らの矛盾も含まないと思われる。以 上で $C_{4}$ についての考察は終るが, これの結晶化速度に 及ぼす効果は分子量が増大すると大きく減少させるもの

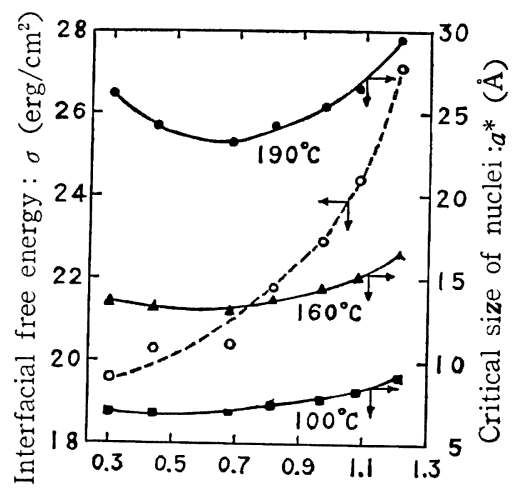

Intrinsic viscosity : $[\eta]$

Fig. 17. Dependence of interfacial free energy and critical size of nuclei upon intrinsic viscosity $[\eta]$.

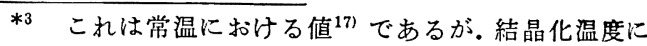
おける值では換算しても。および $a^{*} に$ 対してあ まり大きい影響はない。

*4 1ユニットあたりの体積は室温におけるナイロン 6 の $\alpha$ 型結晶で $15.25 \AA^{3}, \gamma$ 型結晶で $16.2 \AA^{3} て ゙$ ある。ここでは $17 \AA^{3}$ をとった。 
である。しかしながら(15)式の第 4 項全般については， 臨界核寸法について議論したと同様, 分母の $T_{m}-T$ か 分子量依存性を示す低分子量域と高温での結晶化の場合 に $C_{4}$ の変化率以上に大きく寄与して逆に分子量が小さ くなると結晶化速度を減少させる効果を発揮する。した がってある分子量で晶化速度が極大を示すことになるの である。

以上の結晶化に及ぼす譇特性值の分子量依存性を要約 すると，分子量が增大するにつれ，i）ポリマー鎖輸送の 活性化エネルギー $E_{D}$ は $E_{v i s}$ とはその增加傾向を異に して単調に增大する。ii）結晶化に伴らエントロピー変 化は小さくなる。iii）臨界核生成の自由エネルギー, 表 面自由エネルギーは単調に増大する。これらは過冷却状 態厄る融液中のポリマー鎖の状態と結晶（核）の構造 のいず机が分子量に依存して变化していることを意味 するものである。後者, すなわち, 結晶の微細構造の差 異に関しては具体的な知見を持たないが，たとえば高分 子量となるにつれて不完全な檴造となると考えられない こともない。しかし，このことだけで統一して上述の項 は説明できないと思われる。むしろ, 融液中のポリマー 鎖の状態に帰因するとする方が妥当ではなから5か。 ポリマー溶液の粘弾性的性質の濃度依存性は第 1 にポリ マー鎖間のからみ合いに負らとされている。融夜中にお けるこのからみ合い効果はさらに分子鎖長に大きく依存 しているはずである。結晶化核近傍のセグメントは核に まだくり込まれていない部分の鎖の長さとその部分での 他の分子鎖とのからみ合い効果によって, mobility は 減少し融液側に強くけん引されているとい方るだろう。 さらに融液中のポリマー鎖の形態については排除体積効 果 (同し鎖中のセグメントならびにからみ合った他の分 子のセグメントによって自由な配位をとり得ない）によ って小さいェントロピー状態にあると考えられる。前章 で融解温度が低い場合に結晶化速度が大となる結果の一 部を示した（Fig. 1)。他の結晶性ポリマーについても 同様な結果を示すことがわかっている18)。詳細な検討は なされていないがここの原因は鎖の形態が前歷を持つこ と,すなわち，小さいェトロピー状態から結晶化すると 考えてもさしつか克ないたららら。つまり，ii）に関して
は高分子量になるほどェントロピーの小さい状態に対応 した鎖配位にあるためと考劣る。

付記：本研究の発表を許可され，かつご䩒婞を睗 わった東洋紡續瀻維研究所長長井栄一博士および討諭 とご指導を睗わった当所研究室長吉崎修博士に深く 感謝の意を表する。

\section{文献}

1) M. Inoue: J. Polymer Scl., 55, 753 (1961)

2) J. H. Magill: Polymer, 3, 43 (1962)

3) 石橋 徽, 谷 八紘, 吉崎 修, 長井栄一：高化。 23, 177 (1966)

4) 石橋 徽, 谷 八紘, 吉崎 修, 長井栄一：高化, 23, 205 (1966)

5）石橋 徽, 谷 八紘, 吉崎 修, 長井栄一：高化, 23, 208 (1966)

6）福本 修：高分子化学会講演（1955），たとえば 鶴田基弘著：「ポリアミド樹脂」，115，(1961）日 刊工業新聞社

7）上出健二, 稻本義彦, 大野邦夫：高化, 22, 597 (1965)

8） 高柳素夫, 山下達哉：工化，60, 456 (1957)

9）向山鋭次，竹川昭夫：高化, 13, 323 (1956)

10) Y. Wada: J. Phys. Soc. Japan, 16, 1226 (1961)

11) P. J. Flory: "Principles of Polymer Chemistry" Cornell Univ. Press (1953)

12) M. Inoue: J. Polymer Sci., A1, 2697 (1963)

13) M. Dole, B. Wunderlich: Macromol. Chem., 34, 29 (1959)

14）たとえば, 平井西夫：高化, 19, 191 (1962)

15）高柳素夫, 山下達哉, 佐伯康治：工化，60, 299 (1957)

16) J. D. Hoffman, J. J. Weeks, W. M. Murphey: J. Research NBS., 638, 67 (1959)

17) D. R. Holmes, C. W. Bunn, D. J. Smith : J. Polymer Sci., 17, 159 (1955)

18）吉崎 修, 石橋 微, 長井栄一：工化, 65,1614 (1962)

\section{Study on Crystallization of Nylon 6}

\section{Dependence of Isothermal Crystallization Kinetics on} the Molecular Weight and Temperature

By Tohru Ishibashi* and Yatsuhiro Tani*

The rate of crystallization of nylon 6 polymer in bulk form was measured at various temperatures with several kinds of the specimens of different molecular weight $\left(2.6 \times 10^{3}\right.$ to $\left.1.9 \times 10^{4}\right)$ by applying the method of determining the intensity of depolarized light, proposed 
by the authors in the preceding papers. The Avrami's constant $n$ was found to be always 4 except the initial stage of crystallization of the polymer specimen with low molecular weight at higher temperatures, where the value of $n$ was nearly 6 indicating homogeneous nucleation which would lead to sheaf-like crystal growth.

The crystallization rate $1 / t_{1 / 2}$ is expressed by the intrinsic viscosity $[\eta]$, and the crystallization temperature $T$ by the following equation,

$$
\ln \left(\frac{1}{t_{1 / 2}}\right)=\ln T-\frac{E_{D}([\eta])}{R T}+\frac{C_{3}([\eta])}{n}-\frac{C_{4}([\eta])}{n T\left\{T_{m}([\eta])-T\right\}}
$$

where, $n=4$ : Avrami's constant, $E_{D}([\eta])=E_{v i s}([\eta]) / \rho([\eta])$ : activation energy for the transport of material across the liquid-crystal interface (cal/mol), $E_{v i s}([\eta])=4.12 \times 10^{3} \mathrm{~T}^{2} /$ $\left\{51.6+T-T_{0}([\eta])\right\}^{2}$ : activation energy for viscous flow $(\mathrm{cal} / \mathrm{mol}), T_{\theta}([\eta])=581.6-1076 /$ $(1.81[\eta]+13.45)^{0.5}:$ glass transition point $\left({ }^{\circ} \mathrm{K}\right), \rho([\eta])=20.2-8.3[\eta]$ : ratio of $E_{v i s}$ to $E_{D}$, $C_{3}([\eta])=1 /\left(0.309-0.206[\eta]-8.5\right.$ and $C_{4}([\eta])=10^{5} /(0.82-0.52[\eta])+2.5 \times 10^{5}:$ constants independent of $\left.T, T_{\mathrm{m}}([\eta]]\right)$ : melting point $\left({ }^{\circ} \mathrm{K}\right) .1 / T_{m}([\eta])=1 / 504+6.125 \times 10^{-6} /[\eta]^{1.435}$.

Temperature $T_{\max }$ at which the crystallization rate becomes maximum, the value of $E_{D_{\boldsymbol{D}}}$ $\rho$, activation entropy, included in $C_{3}$ for crystallization interfacial free energy and the size of critical nuclei derived from $C_{4}$ are all dependent on the molecular weight of polymer.

\footnotetext{
* Fiber Research Institute, TOYOBO Co., Ltd. (Honkatata, Otsu, Shiga)
} 